\title{
PENEGAKKAN HUKUM ATAS PENGAWASAN PEMBAWAAN UANG TUNAI BERDASARKAN PERATURAN PERUNDANG- UNDANGAN
}

\author{
Retta Ayu Urip Mawarni \\ miss_raum@gmail.com \\ Universitas Airlangga
}

\begin{abstract}
There are interesting issues related to the supervision of the carrying of cash by the perpetrators carrying cash into and out of the territory of the Unitary State of the Republic of Indonesia is growing, especially the exchange of rupiah money against foreign money amounting to Rp. 100,000,000.00 at a money changer. But on the other hand, the effect of the perpetrator brings the money in large denominations abused as bribery and as tracking the flow of funds to other parties receiving funds by the perpetrator. Reflecting on the issue, in order to combat money laundering, there are two institutions: the Directorate General of Customs and the Financial Transaction Analysis Reporting Center is authorized to follow up the perpetrators who do not carry out the cash carrying report because the Directorate General of Customs and the Financial Transaction Analysis Reporting Center as the main focus of prevention of the perpetrators the carrying of cash in and out of the country as stipulated in the Money Laundering Act and in the case of prevention of the perpetrator is required to execute and notify the cash carrying report must not exceed $R p$ 100.000.000,00 so as not to be subject to criminal sanctions and administrative sanctions and prevent financial which is engineered.
\end{abstract}

Keywords: Reporting Obligations; Custodial Performers; Criminal Accountability.

\begin{abstract}
Abstrak
Terdapat permasalahan yang menarik terkait pengawasan pembawaan uang tunai oleh pelaku pembawaan uang tunai ke dalam maupun ke luar wilayah Negara Kesatuan Republik Indonesia semakin berkembang terutama penukaran uang rupiah terhadap uang asing sejumlah Rp. 100.000.000,00 di tempat penukaran uang. Namun di sisi lain, akibat dari pelaku tersebut membawa uang dalam pecahan besar disalahgunakan sebagai penyuapan dan sebagai pelacakan aliran dana kepada pihak lain yang menerima dana oleh pelaku tersebut. Berkaca dari permasalahan tersebut, guna memberantas pencucian uang maka terdapat dua institusi yaitu Direktorat Jenderal Bea Cukai dan Pusat Pelaporan Analisis Transaksi Keuangan berwenang menindaklanjuti pelaku yang tidak melaksanakan laporan pembawaan uang tunai karena Direktorat Jenderal Bea Cukai dan Pusat Pelaporan Analisis Transaksi Keuangan sebagai fokus utama pencegahan pelaku pembawaan uang tunai ke dalam maupun ke luar negeri sebagaimana tertuang pada Undang-Undang Pencucian Uang serta dalam hal pencegahan pelaku diwajibkan melaksanakan dan memberitahukan laporan pembawaan uang tunai tidak boleh melebihi Rp 100.000.000,00 agar tidak dikenai sanksi pidana dan sanksi administrasi dan mencegah keuangan yang direkayasa.
\end{abstract}

Kata Kunci: Kewajiban Pelaporan; Pelaku Pembawa Uang Tunai; Pertanggungjawaban Pidana.

\section{Pendahuluan}

Pencucian uang atau money laundry, merupakan aset pelaku terkait aset tunai yang di dapatkan dari tindak pidana, di sembunyikan, hilangkan bahkan dikaburkan 
sedemikian rupa sehingga aset tersebut seolah-olah berasal dari sumber yang sah, sehingga sumber perolehan tersebut illegal dan dilarang oleh negara melalui peraturan perundang-undangan dengan merubah menjadi legal melalui penempatan (placement), penyebaran (layering), dan pengumpulan (integration). ${ }^{1}$

Amerika menggunakan pertama kali pada tahun 1982 istilah money laundering disebabkan kepada pencucian hak milik mafia dengan cara memperoleh secara gelap untuk pencampuran selanjutnya dijadikan hasilnya seolah-olah menjadi sumber sah serta kasusnya berkaitan dengan denda melalui pencucian uang hasil penjualan kokain Kolombia. ${ }^{2}$

Seiring berjalannya waktu proses tersebut lebih kompleks dengan cara sedemikian rupa yang pada pada akhirnya uang tersebut sungguh alami. Sementara Pusat Pelaporan Analisis Transaksi Keuangan mengatakan pencucian uang merupakan menyembunyikan, menghilangkan bahkan mengkaburkan asal usul hasil kejahatan. ${ }^{3}$

Pengungkapan sumber perolehan tersebut merupakan kepentingan penghilangan jejak bagi pelaku untuk menikmati keuntungan dengan cara melakukan penjualan senjata illegal, perdagangan manusia dan kegiatan kegiatan lain yang dapat menghasilkan uang banyak dengan menghalalkan (legitimasi) hasil dari money laundering maupun dengan money laundering sebagai bentuk dari cyber crime. ${ }^{4}$

Dunia Internasioanl sudah melihat masalah pencucian uang sebab dimensi dan implikasi pada pelanggaran batas-batas negara. Amerika terdapat Al Capone adalah penjahat terbesar melakukan pencucian uang hitam dari usaha kejahatan dengan Meyer Lansky (berasal dari Polandia juga akuntan melakukan kejahatan pencucian uang Al Capone melalui usaha pencucian dan hal tersebut muncul Money

1 M. Giovanoli dari Bank International Settlement dalam makalah Grace Y. Bawole, Sistem Pembuktian dalam Tindak Pidana Pencucian Uang di Indonesia Menurut Undang-Undang Nomor 23 Tahun 2004 (Fakultas Hukum Universitas Sam Ratulangi 2011).

2 Yenti Garnasih 'Anti Pencucian Uang Sebagai Strategi Untuk Memberantas Kejahatan Keuangan (Profit Oriented Crimes)’ (2006) 2 Jurnal Hukum Progresif.[40].

3 Ibid.

4 Yati Garnasih, Kriminalisasi Pencucian Uang (Universitas Indonesia Fakultas Hukum Pasca Sarjana 2003).[5]. 
Laundering atau Pencuian Uang. ${ }^{5}$

Tahun 1930 di Amerika Serikat, pencucian uang atau money laundering, yaitu saat mafia melakukan pembelian perusahaan sah dan resmi untuk strateginya. Salah satu investasinya adalah perusahaan pencucian pakaian atau Laundromat di Amerika Serikat. Usaha pencucian itu berkembang pesat maupun berbagai perolehan uang hasil kejahatan misalnya dari cabang usaha lainnya ditanamkan ke usaha pencucian pakaian ini, uang hasil minuman keras illegal, hasil perjudian, bahkan hasil usaha pelacuran. ${ }^{6}$

Money laundering memang berawal dilakukan terhadap uang dengan memperoleh lalu lintas perdagangan narkotik dan obat-obat sejenis maupun drug trafficking. Namun untuk dilakukan pada uang yang diperoleh dari sumber kejahatan lain. Pengumpulan uang haram secara internasional berasal dari drug trafficking bukan sumber utama namun berasal dari tax evision, flight capital, dan dari irregulator or hiden economies yang dibedakan dari overly criminal economies. Flight capital, termasuk uang yang sudah tersedia dari negara maju (developed countries) berupa bantuan keuangan (financial aid), dengan tidak dibelanjakan atau diinvestasikan dinegara yang bersangkutan, tetapi negara berkembang sebagai illegal exported capital karena uang tersebut ditempatkan di bank luar negeri dengan memberikan kredit tersebut. ${ }^{7}$

Ada banyak faktor keuntungan money laundering di Indonesia yang menyebabkan tidak ragu dicap negara tidak kooperatif untuk memerangi jenis kejahatan pencucian uang diantaranya penunjukkan sistem devisa bebas, kerahasiaan bank namun Indonesia membutuhkan likuiditas maupun belum ada aturan tegas bagi anti pencucian uang. Tahun 2001 tanggal 22 Juni, Pusat Pelaporan Analisis Transaksi Keuangan menyatakan Indonesia dan 19 negara lain termasuk kawasan yang tidak koperatif terhadap penanganan kasus money laundering diantaranya 19 negara lain tersebut adalah Mesir, Rusia, Hongaria, Israel, Lebanon, Filipina,

\footnotetext{
5 Adrian Sutedi, Hukum Perbankan: Suatu Tinjauan Pencucian Uang, Merger dan Kepailitan (Sinar Grafika 2008).[17].

6 Ibid.

$7 \quad$ Ibid.[16].
} 
Myanmar, Nauru, Nigeria, Niue, Cook Island, Republik Dominika, Guatemala, St. Kitts and Nevis, St. Vincent dan Grenadines serta Ukraina. ${ }^{8}$

Indonesia memiliki Pusat Pelaporan Analisis Transaksi Keuangan bertindak melakukan pemberantasan Pencucian Uang. Pertama kali Presiden Republik Indonesia melakukan penunjukkan kepada Yunus Husein dan I Gede Sadguna sebagai kepala dan wakil kepala Pusat Pelaporan Analisis Transaksi Keuangan serta tanggal 15 januari 2013 telah melakukan penandatanganan perjanjian dengan Asian Development Bank terkait bantuan teknis dalam melaksanakan Undang-Undang Tahun 2002 terkait pencucian uang sebagaimana telah diubah dengan UndangUndang Tahun 2003. Secara Yuridis, untuk memerangi pencucian uang diawali diundangkannya Undang-Undang Tahun 2002, Undang-Undang Tahun 2003 dan terbaru yaitu Undang-Undang Tahun 2010 terkait Pencegahan dan Pemberantasan Tindak Pidana Pencucian Uang. PPATK adalah institusi independen dengan tugas dan wewenang dalam rangka pemberantasan pencucian uang di Indonesia, utamanya yakni: melakukan pendendeteksian terjadinya pencucian uang dan membantu penegakan hukum berkaitan dengan pencucian uang dan pidana asal (predicate crimes), sehingga peranan kunci dan mekanisme pemberantasan pencucian uang di Inonesia ada pada tangan Pusat Pelaporan Transaksi Analisis Keuangan atau PPATK. Sebab, apabila PPATK tidak melakukan fungsi secara benar, maka efektivitas pelaksanaan Undang-Undang Pencucian Uang tidak akan terlaksana. ${ }^{9}$

Dalam pratek pencegahan Pencucian Uang, Pusat Pelaporan Analisis Transaksi Keuangan atau financial Intelligence Unit adalah institusi intitusi permanen terhadap penanganan masalah pencucian uang yang bertanggungjawab kepada Presiden dan dilakukan kerjasama dalam rangka penegakkan hukum,dilakukan kerjasama dengan sektor keuangan, laporan masuk dianalisis, seluruh data dan aset yang ada dilakukan pengamanan, dilakukan kerjasama dan fungsi administrasi umum.

\footnotetext{
${ }^{8}$ N.H.T Siahaan, Pencucian Uang dan Kejahatan Perbankan (Pustaka Sinar Harapan 2005).[2].

9 Ivan Yustiavandana, Arman Nefi dan Adiwarman, Tindak Pidana Pencucian Uang di Pasar Modal (Ghalia Indonesia 2010).[219].
} 
Penanggulangan Pencucian Uang tidak berjalan baik tapa ada campur tangan undang-undang tersebut sehingga pencegahan pencucian uang di Indonesia ada pada institusi Pusat Pelaporan Analisis Transaksi Keuangan. ${ }^{10}$

Di Indonesia, Pusat Pelaporan Analisis Transaksi Keuangan sebagai Unit Intelijen Keuangan dimaknai strategis terhadap pencegahan pencucian uang karena membawa perubahan dengan diperkuatkannya peran Pusat Pelaporan Analisis Transaksi Keuangan sebagai fokus utama dalam pencegahan Pencucian Uang di Indonesia. Peran Pusat Pelaporan Analisis Transaksi Keuangan tersebut diantaranya dengan ditingkatkan tugas, fungsi dan wewenang Pusat Pelaporan Analisis Transaksi Keuangan, dipertegas pengaturan dan perluasan pihak pelapor, diperluas lembaga pada penyelidikan dan penyidikan tindak pidana pencucian uang. ${ }^{11}$

Untuk peningkatan upaya dan dugaan pada pengungkapan praktik pencucian uang maka Pusat Pelaporan Analisis Transaksi Keuangan melakukan sebagai berikut: ${ }^{12}$

a. Guna pemenuhan kewajiban maka pihak pelapor melakukan peningkatan penyampaian laporan kepada Pusat Pelaporan dan Analisis Transaksi Keuangan;

b. pihak pelapor melakukan hasil analisis dan pemeriksaan atas laporan dan informasi berdasarkan kualitas dan kuantitas.

c. ditingkatkan hasil riset untuk mendeteksi tipologi maupun modus Pencucian Uang;

d. ditingkatkan efektivitas penyampaian Laporan Hasil Analisis dan Laporan Hasil Pemeriksaa kepada Aparat Penegak Hukum, serta terpantaunya tindak lanjut pengungkapan kasus pencucian uang.

Pada mulanya pencucian uang tertuang pada Undang-Undang lama tahun 2002 terkait Tindak Pidana Pencucian Uang kemudian diubah Undang-Undang tahun 2003, selanjutnya pemerintah menyempurnakan Undang-Undang tersebut. Dengan tujuan sebagai berikut: ${ }^{13}$

1. perumusan laporan keuangan tunai dengan pembatasan dan kepada ditujukan

\footnotetext{
${ }^{10}$ Sutan Remy Sjahdeini, Seluk Beluk Tindak Pidana Pencucian Uang dan Pembiayaan Terorisme (Pustaka Utama Grafiti 2004).[248].

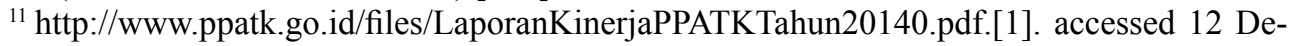
sember 2015.

12 Ibid.[18].

${ }^{13}$ Yunus Husein, 'Rancangan Undang-Undang Tentang Pembatasan Transaksi Tunai', http://www.bphn.go.id/data/documents/naskah_akademis_ruu_tentang_pembatasan_transaksi_tunai.pdf (2013).[6], accessed 28 September 2014.
} 
kepada siapa saja pembatasan ini dilakukan.

2. Menghadapi dengan digambarkan permasalahan kehidupan berbangsa, bernegara dan bermasyarakat, selanjutnya penyelesaian tersebut diperlukan pengaturan terkait pembatasan laporan keuangan tunai.

3. Pengaturan Pembatasan Laporan Keuangan Tunai dengan diuraikan argumentasi filosofis, sosiologis dan yuridis.

4. Pengaturan pembatasan Laporan Keuangan Tunai diuraikan dengan memperhatikan dampak sosial, ekonomi, dan budaya.

5. Pengaturan pembatasan Laporan Keuangan Tunai dielaborasikan dengan sasaran, arah, jangkauan, dan ruang lingkup.

6. Pengaturan pembatasan Laporan Keuangan Tunai diuraikan dengan sanksi terhadap setiap orang yang melanggar ketentuan.

7. Pengaturan pembatasan Laporan Keuangan Tunai ditentukan instansi yang memiliki kewenangan dengan pengawasan.

Pencapaian Naskah Akademik Rancangan Undang-Undang Pembatasan Laporan Keuangan Tunai adalah terwujudnya laporan keuangan efisien, aman, cepat, modern dan tercatat terhadap sistem keuangan dan sistem pembayaran sehingga bermanfaat untuk melacak ruang gerak penggunaan laporan keuangan tunai guna mencegah pencucian uang, seperti korupsi, narkoba ataupun lainnya. ${ }^{14}$

Di Indonesia, Rencana Strategi dan strategi penguatan rezim anti pencucian uang tersebut di atas merupakan kerangka acuan dan pedoman yang hendak dilakukan dan akan dituju dalam upaya pencucian uang di selama 4 tahun dari 2007 sampai 2011. Dengan acuan tersebut akan dapat dievaluasi kinerja keberhasilan maupun kendala yang diadapi untuk selanjutnya akan dilakukan perbaikanperbaikan strategi ke depan dalam memaksimalkan pencegahan pencucian uang. ${ }^{15}$

Beberapa negara, seperti Austria, Finlandia, Jerman, Irlandia, Luxemburg, Portugal, Spanyol, Swedia, Inggris, Italia, Meksiko, Perancis, Belgia, Armenia, Bulgaria, dan Ukraina sudah melakukan pembatasan laporan keuangan tunai terkait pembatasan pembayaran tunai antar individu, penukaran valuta asing secara tunai, dan pembelian barang dan/jasa serta terdapat pengecualian atau

\footnotetext{
${ }^{14}$ Ibid. [86].

${ }^{15}$ Toetik Rahayuningsih, Analisis Peran PPATK Sebagai Salah Satu Lembaga Dalam Menanggulangi Money Laundering Di Indonesia (2013) 28 Yuridika.[318].
} 
kondisi-kondisi tertentu yang aturan tersebut tidak diterapkan serta penerapan sanksi bagi pelanggar aturan tersebut. ${ }^{16}$

Negara semua hampir melakukan pembatasan laporan keuangan tunai dengan cara pelarangan membeli barang mewah dan properti melalui pembayaran secara tunai dalam jumlah tertentu. Contohnya Meksiko, hanya diperbolehkan pembayaran tunai untuk membelikan barang maupun jasa maksimal USD100 (Rp.100 juta). Adapun, pemerintah Meksiko tengah dirancang peraturan melarang membeli real estate secara tunai dan melarang seseorang menghabiskan uang tunai lebih dari MXN 100.000 (Rp. 80.000.000,00) sebagai keperluan pembelian kendaraan, kapal, pesawat, dan barang mewah. Pada usulan terhadap pelanggar bisa dikenakan pidana hingga 15 tahun penjara. ${ }^{17}$

Pemerintah Belgia dilarang membelikan real property dengan tunai melebihkan dari EUR 5.000 (Rp. 64.000.000,00). Kemudian, Prancis dilarang pembayaran melebihkan dari EUR 1.100 (Rp.14.000.000,00) atau untuk pelunasan hutang lebih besar berkaitan dengan sewa, transportasi, jasa, perlengkapan, pekerjaan, akuisisi property, benda-benda bergerak maupun berkaitan pendapatan dari surat berharga, premi asuransi maupun kontribusi. ${ }^{18}$

Negara tersebut diterapkan pengecualian terhadap pembatasan laporan keuangan tunai. Namun Prancis dibolehkan transaksi tunai untuk melakukan pembayaran langsung oleh individu (pribadi) yang bukan pedagang kepada individu (pribadi) lain, makelar atau pedagang. Selanjutnya pembelian ternak maupun daging mentah dilakukan oleh individu (pribadi) untuk konsumsi sendiri maupun oleh seorang petani ke petani lain, melalui syarat para pihak yang bersangkutan juga terlibat dalam pekerjaan non pertanian yang keperluannya transaksi tersebut. Tidak ada pembatasan terhadap pembayaran belanja pemerintah, otoritas publik, atau lembaga publik. ${ }^{19}$

\footnotetext{
${ }^{16}$ Andri Gunawan, Erwin Natosmal Oemar, membatasi transaksi tunai peluang dan tantangan, http://www.ilr.or.id/wp-content/upload/2013/05/membatasi-FINAL-03-BW.pdf, accessed 1 Oktober 2014.[59].

${ }^{17}$ Ibid.

18 Ibid.[60].

19 Ibid.
} 
Bulgaria tetap dibolehkan laporan keuangan tunai melalui: (1) penarikan/ penyetoran tunai maupun rekening pembayaran pribadi; (2) penarikan/penyetoran tunai maupun rekening individu secara hukum tidak kompeten maupun individu dengan kompetensi hukum terbatas, pasangan, maupun kerabat lineal; (3) laporan keuangan tunai dalam mata uang asing dalam rangka pekerjaan/jabatan; (4) laporan keuangan tunai yang dilakukan secara internal oleh Bank Nasional Bulgaria; (5) laporan keuangan tunai yang berkaitan melalui penggantian uang kertas Bulgaria yang rusak dan uang logam oleh bank; dan (6) pembayaran remunerasi terhadap undang-undang perburuhan. Mengenai pengenaan sanksi bagi pelanggar larangan transaksi tersebut, memberlakukan sanksi denda. Meksiko melakukan penerapan sanksi pidana penjara sedangkan Italia menerapkan denda sebesar 10-40 persen dari nilai uang dengan transaksi atau dari nilai sisa saldo rekening.Belgia menjatuhkan denda paling sedikit EUR 250 dan paling banyak banyak EUR 225.000. Tidak boleh melebihi $10 \%$ dari nilai transaksi tunai yang merupakan ketentuan objek denda. Bulgaria dibedakan sanksi denda sebesar 25 persen dari jumlah total pembayaran untuk pelanggar bagi individu atau perorangan, sedangkan untuk badan hukum dikenakan denda sebesar 50 persen dari jumlah total pembayaran. Apabila pelanggaran itu dilakukan lagi, serta jumlah sanksi dengan meningkatkan menjadi dua kali lipat. ${ }^{20}$

Proses tersebut harus mencakup kewenangan untuk: (a) mengidentifikasi, melacak, dan mengevaluasi properti yang dikenakan penyitaan; (b) melaksanakan tindakan sementara seperti: pembekuan dan merebut untuk mencegah transaksi, transfer atau pelepasan properti tersebut; (c) mengambil langkah-langkah yang akan mencegah atau tindakan kekosongan yang merugikan kemampuan negara untuk membekukan atau menyita atau memulihkan properti yang dikenakan penyitaan dan (d) mengambil langkah-langkah investigasi yang tepat. ${ }^{21}$

Jadi negara keseluruhan melakukan pertimbangan untuk mengambil langkah-

\footnotetext{
${ }^{20}$ Ibid.[61-62].

${ }^{21}$ Hernold Ferry Makawimbang, Memahami dan Menghindari Perbuatan Merugikan Keuangan Negara Dalam Tindak Pidana Korupsi dan Pencucian Uang (Thafa Media 2015).[250].
} 
langkah dengan hasil atau sarana tersebut untuk disita tanpa diperlukan hukuman pidana atau dibutuhkan pelaku untuk ditunjukkan asal properti halal diduga menggunakan penyitaan, sebagai persyaratan tersebut melalui prinsip hukum nasional. ${ }^{22}$

Dari uraian tersebut, maka penulis terdorong dan tertarik untuk mengetahui lebih lanjut mengenai Undang-Undang Nomor 25 Tahun 2003 tentang Pencucian Uang telah diubah dengan Undang-Undang Nomor 8 Tahun 2010 diantaranya memuat ketentuan baru yaitu Kewajiban Pelaporan Tunai maupun Instrumen Pembayaran Lain Ke Dalam atau Ke Luar Daerah Pabean yang diterapkan Penyedia Jasa Keuangan untuk mengetahui penegakkan hukum dan pertanggungjawaban kewajiban pelaporan pembawaan uang tunai, sehingga kiranya penting untuk membahas tindak pidana pencucian uang yang dilakukan dalam aktivitas kepabeanan dikarenakan hal tersebut menjaga stabilitas nilai tukar mata uang rupiah dan mencegah internasionalisasi mata uang rupiah serta dalam pencegahan dan pemberantasan Tindak Pidana Pencucian Uang di Indonesia.

\section{Pengaturan Kewajiban Pelaporan Dalam Hal Pembawaan Uang Tunai Lebih Dari Rp. 100.000.000,00 Menurut Peraturan Perundang-Undangan.}

Kewajiban Pelaporan terkait pengawasan pembawaan uang tunai lebih $\mathrm{Rp}$ 100.000.000,00 tertuang pada Undang-Undang Pencucian Uang.

Pihak Pelapor berkewajiban memberikan informasi terkait pembawaan uang tunai adalah setiap orang. Menurut Peraturan Presiden Nomor 11 Tahun 2011, sama artinya pada Undang-Undang Pencucian Uang wajib melakukan laporan pada Pusat Pelaporan dan Analisis Transaksi Keuangan. Sedangkan Direktorat Jenderal Bea Cukai dengan Pusat Pelaporan Analisis Transaksi Keuangan melakukan kewajiban pelaporan pembawaan tunai .

Undang-Undang Pencucian Uang mengatur pihak pelapor yaitu pihak-pihak yang diberi kewajiban pelaporan dan ditentukan laporan yang wajib disampaikan kepada Pusat Pelaporan Analisis Transaksi Keuangan adalah laporan sebagai berikut: ${ }^{23}$

${ }^{22}$ Ibid.

${ }^{23}$ R. Wiyono, Pembahasan Undang-Undang Pencegahan dan Pemberantasan Tindak Pidana Pencucian Uang, cet. 2 (Sinar Grafika 2014).[33]. 
a. Laporan Keuangan Mencurigakan;

b. Laporan Keuangan Tunai Rp 500.000.000,00 atau uang asing yang setara untuk satu kali transaksi atau beberapa kali transaksi pada 1 (satu) hari kerja (Pasal 23 ayat 1 huruf b);

c. Laporan Keuangan Transfer Dana Dari Atau Keluar Negeri (Pasal 23 ayat 1 huruf c);

d. Laporan dari Penyedia Barang Jasa Lain terhadap transaksi oleh Pengguna Jasa dengan mata uang rupiah dan mata uang asing setara dengan $\mathrm{Rp}$ 500.000.000,00 (Pasal 27 ayat 1);

e. Laporan dari penyedia jasa keuangan yang melakukan pemutusan hubungan usaha dengan Pengguna Jasa (pasal 22 ayat 2);

f. Laporan dari Direktorat Jenderal Bea Cukai terkait pembawaan uang tunai maupun instrumen pembayaran lain (Pasal 34 ayat 1).

Aturan pada Pasal 23 ayat (1) dan Pasal 27 ayat (1), dapat dikatakan bahwa laporan seperti pada butir a, b, dan c wajib disampaikan oleh Penyedia Jasa Keuangan sedangkan pada Pasal 17 ayat (1) huruf a kepada Pusat Pelaporan Analisis Transaksi Keuangan, serta pada butir d wajib disampaikan oleh penyedia barang jasa lain tertuang pada Pasal 17 ayat (1) huruf b juga pada Pusat Pelaporan Analisis Transaksi Keuangan. ${ }^{24}$

Dengan demikian pengertian dari "Pihak Pelapor" dalam Pasal 1 angka 11 sebenarnya hanya tertentu dan terbatas pada orang perseorangan atau korporasi yang hanya disebutkan dalam: ${ }^{25}$

a. Pasal 17 ayat (1) huruf a maupun huruf $b$.

b. Peraturan Pemerintah dari Pasal 17 ayat (2).

c. Pasal 34 ayat (1).

Undang-Undang Pencucian Uang mengatur hal batasan jumlah tunai dibawa ke luar maupun masuk ke dalam daerah pabean di Indonesia. Pembatasan jumlah uang tunai ini dimaksudkan untuk meminimalisasi potensi Pencucian Uang terkait modus membawa keluar maupun masuk ke dalam daerah pabean Indonesia. ${ }^{26}$

Dengan adanya kewajiban pelaporan bagi pelaku membawa ke luar maupun

\footnotetext{
${ }^{24}$ Ibid.

${ }^{25}$ Ibid.[34].

${ }^{26}$ Yudi Kristiana, Pemberantasan Tindak Pidana Pencucian Uang Perspektif Hukum Progresif(Thafa Media 2015).[133].
} 
masuk ke dalam daerah pabean Indonesia dimaksudkan untuk pelaku membawa uang lebih Rp 100.000.000,00 itu dapat mempertanggungjawabkan uang yang dibawa baik dari sisi perolehan maupun peruntukan. Hal tersebut sangat penting karena uang tunai dalam jumlah besar patut dicurigai sebagai salah satu bentuk transaksi yang mencurigakan, mengingat kalau memang uang tersebut dimaksudkan hanya untuk kepentingan harian yang sifatnya personal. Demikian juga kalau memang dimaksudkan untuk melakukan transaksi dalam jumlah yang besar, sudah barang tentu tidak dilakukan dalam bentuk tunai. Itulah sebabnya ada kewajiban untuk melaporkan karena dengan demikian kalau memang diperlukan uang tunai dalam jumlah besar akan diketahui kewajaran peruntukannya. ${ }^{27}$

Kewajiban pelaporan ini tidak hanya terbatas pada uang tunai dalam bentuk rupiah tetapi juga dalam bentuk mata uang asing, ${ }^{28}$ Ketentuan aturan uang tunai dalam Pasal 34 sebagai berikut: ${ }^{29}$

(1)Orang yang membawa tunai dalam mata uang rupiah maupun mata uang asing, serta instrumen pembayaran lain dalam bentuk cek, cek perjalanan, surat sanggup bayar, atau bilyet giro paling sedikit Rp100.000.000,00 (seratus juta rupiah) atau yang nilainya setara dengan itu ke dalam atau ke luar daerah pabean Indonesia wajib memberitahu-kannya pada Direktorat Jenderal Bea Cukai.

(2)Direktorat Jenderal Bea dan Cukai wajib membuat laporan mengenai pembawaan uang tunai dan/atau instrumen pembayaran lain tertuang pada ayat (1) dan menyampaikannya kepada Pusat Pelaporan Analisis Transaksi Keuangan paling lama 5 hari kerja sejak diterimanya pemberitahuan.

(3)Pusat Pelaporan Analisis Transaksi Keuangan dapat meminta informasi tambahan dari Direktorat Jenderal Bea Cukai mengenai pembawaan uang tunai maupun instrumen pembayaran lain sebagaimana tertuang dalam ayat (1).
${ }^{27}$ Ibid.
${ }^{28}$ Ibid.
${ }^{29}$ Ibid. [134]. 
Direktorat Jenderal Bea Cukai adalah penyidik Tindak Pidana Pencucian Uang yang menindaklanjuti Hasil Analisis maupun Hasil Pemeriksaan Pusat Pelaporan Analisis Transaksi Keuangan juga wajib membuat laporan mengenai pembawaan tunai maupun instrumen pembayaran lain. ${ }^{30}$

\section{Peraturan Tata Cara Membawa Uang Rupiah Keluar atau Masuk Wilayah Pabean Republik Indonesia.}

Peraturan Tata Cara Membawa Uang Rupiah Keluar atau Masuk Wilayah Pabean Republik Indonesia atau Peraturan Bank Indonesia ini menggantikan Peraturan lama tentang Persyaratan dan Tata Cara Membawa Uang Rupiah Keluar atau Masuk Wilayah Pabean Republik Indonesia tidak sesuai dengan situasi dan kondisi serta kebutuhan hukum dalam masyarakat sehingga substansinya perlu diatur kembali agar sesuai dengan Undang-Undang Pencucian Uang. Peraturan Tata Cara Membawa Uang Rupiah Keluar atau Masuk Wilayah Pabean Republik Indonesia untuk menghindari penerapan yang rancu dan memberikan kepastian bagi masyarakat, sehingga aturan tata cara membawa Uang Rupiah keluar atau masuk wilayah pabean Republik Indonesia saat ini berlaku perlu diselaraskan dengan Undang-Undang Pencucian Uang. sehingga menjadi instrumen pengaturan pembawaan fisik secara lintas batas negara dapat diminimalkan karena berdampak kurang pada keuntungan bagi efektifitas kebijakan moneter. Selain itu, masyarakat perlu dikuatkan kepercayaan terhadap uang Rupiah dengan cara peningkatan pengawasan dalam mengedarkan uang palsu ke masyarakat dengan mencegah masuknya Rupiah palsu dari luar negeri. ${ }^{31}$

Dalam ketentuan Peraturan Bank Indonesia dijelaskan aturan wajib pelaporan pembawaan uang rupiah Rp.5.000.000,00 sampai dengan Rp.10.000.000,00 dan kewajiban pelaporan disertai perizinan pembawaan uang rupiah di atas $\mathrm{Rp}$.

\footnotetext{
${ }^{30} \mathrm{http}: / / w w w . p p a t k . g o . i d / f i l e s / L a p o r a n T a h u n a n 20141$.pdf, accessed 12 Oktober 2015.

${ }^{31}$ Peraturan Bank Indonesia baru terkait Tata Cara Membawa Uang Rupiah Keluar atau Masuk Wilayah Pabean Republik Indonesia (Lembaran Negara Republik Indonesia Tahun 2002 Nomor 104, Tambahan Lembaran Negara Republik Indonesia Nomor 4231), Penjelasan Umum.
} 
10.000.000,00 sebagai berikut :

Pasal 2

(2) Pelaku membawa Uang Rupiah keluar wilayah Republik Indonesia lebih dari Rp.5.000.000,00 (lima juta rupiah) sampai dengan Rp.10.000.000,000 (sepuluh juta rupiah), wajib terlebih dehulu mendeklarasikan pembawaan Uang Rupiah keluar wilayah Republik Indonesia di tempat keberangkatan.

(3) Pelaku membawa Uang Rupiah keluar wilayah Republik Indonesia lebih dari Rp.10.000.000,00 (sepuluh juta rupiah), wajib terlebih dahulu memperoleh izin secara tertulis dari Bank Indonesia serta mendeklarasikan pembawaan Uang Rupiah keluar wilayah Republik Indonesia di tempat keberangkatan.

Pasal 3

(2) Pelaku membawa Uang Rupiah masuk wilayah Republik Indonesia lebih dari Rp.50.000.000,00 (lima juta rupiah) sampai dengan Rp.100.000.000,00 (seratus juta rupiah) wajib terlebih dahulu mendeklarasikan pembawaan Uang Rupiah masuk wilayah Republik Indonesia di tempat kedatangan.

(3) Pelaku membawa Uang Rupiah masuk wilayah Republik Indonesia lebih dari Rp.100.000.000,00 (seratus juta rupiah), wajib terlebih dahulu mendeklarasikan pembawaan Uang Rupiah masuk wilayah Republik Indonesia dan memeriksakan keaslian uangnya di tempat kedatangan.

Peraturan Bank Indonesia baru yang terbit 10 Oktober 2002 telah mencabut peraturan tersebut Peraturan Bank Indonesia lama dalam Pasal 2 dan Pasal 3 terkait meniadakan kewajiban pelaporan, perizinan dan pemeriksaan atas pembawaan uang rupiah masuk dan keluar pabean Indonesia untuk jumlah uang rupiah Rp.100.000.000,00 atau lebih sebagai berikut :

Pasal 2

Pelaku membawa Uang Rupiah sebesar Rp. 100.000.000,00 atau lebih keluar wilayah pabean Republik Indonesia, wajib terlebih dahulu memperoleh izin dari Bank Indonesia.

Pasal 3

Pelaku membawa Uang Rupiah sebesar Rp.100.000.000,00 atau lebih keluar 
wilayah pabean Republik Indonesia, wajib terlebih dahulu memeriksakan keaslian uang tersebut kepada petugas Bea dan Cukai di tempat kedatangan. Ditegaskannya pengertian perubahan aturan tersebut didasarkan pada Undang-Undang Pencucian Uang lama dan aturan baru tersebut tidak berpengaruh banyak terhadap lalu lintas keluar masuknya rupiah dari dan ke Indonesia serta guna memperketat keluarnya uang rupiah terhadap Bank Indonesia maka diberikan kepentingan sebagai berikut:

Pasal 4

(1) Izin Bank Indonesia tertuang pada Pasal 2 ayat (3) hanya dapat diberikan untuk kepentingan :

a. Penyediaan uang untuk kebutuhan negara;

b. Uji coba mesin uang;

c. Kegiatan pameran di luar negeri.

Pengecualian kepentingan tersebut untuk memberantas kegiatan pencucian uang yang dilakukan oleh pelaku pembawa uang tunai.

\section{Peraturan Tata Laksana Pengeluaran dan Pemasukan Uang Tunai.}

Dalam upaya memberantas pencucian uang agar berjalan secara efektif, menjaga dan memelihara kestabilan nilai uang rupiah serta pengawasan lalu lintas peredaran uang termasuk pengawasan terhadap uang palsu kedalam Daerah Pabean, perlu ada aturan tata laksana pengeluaran atau pemasukan uang tunai dengan peraturan tersebut. ${ }^{32}$

Peraturan Direktorat Jenderal Bea Cukai tanggal 19 Januari 2005 terkait Tata Laksana Pengeluaran dan Pemasukan Uang Tunai mengenai prosedur pembawaan uang secara spesifik sebagai berikut:

Pasal 2

(1) Pelaku membawa uang tunai berupa rupiah sejumlah Rp.100.000.000,00 (seratus juta rupiah) atau lebih, atau mata uang asing yang nilainya setara

\footnotetext{
${ }^{32}$ Peraturan Tata Laksana Pengeluaran dan Pemasukan Uang Tunai, Konsideran huruf b.
} 
dengan itu, keluar dari Daerah Pabean wajib memberikan laporan kepada pejabat Bea dan Cukai.

(2) Laporan sebagaimana dimaksud pada ayat (1) dilakukan dengan mengisi dan menyerahkan :

a. Pemberitahuan Pembawaan Mata Uang Tunai Keluar Daerah Pabean (BC 3.2) jika dibawa langsung oleh penumpang.

b. Pemberitahuan Ekspor Barang (BC 3.0) jika diekspor sebagai barang kargo atau melalui Perusahaan Jasa Titipan (PJT)

Pasal 3

(1) Pelaku membawa uang tunai berupa rupuah sejumlah $\mathrm{Rp} 100.000 .000,00$ (seratus juta rupiah) atau lebih, atau mata uang asing yangnilainya setara dengan itu, ke dalam Daerah Pabean wajib memberikan laporan kepada Pejabat Bea dan Cukai.

(2) Laporan sebagimana dimaksud pada ayat (1) dilakukan dengan mengisi dan menyerahkan:

a. Customs Declaration (BC 2.2) jika dibawa langsung oleh penumpang;

b. Pemberitahuan Impor Barang (BC 2.0) jika diimpor sebagai barang kargo;

c. Pemberitahuan Impor Barang Tertentu (BC 2.1) jika melalui Perusahaan Jasa Titipan (PJT).

(3) Apabila yang dibawa adalah uang tunai berupa rupiah maka setiap orang sebagaimana dimaksud pada ayat (1) wajib memeriksakan keaslian uang rupiah tersebut kepada Pejabat Bea dan Cukai.

Langkah peran penting Direktorat Jenderal Bea Cukai pada tahapan upaya pencucian uang adalah dengan menindaklanjuti pembawaan uang lintas negara sehingga Bea Cukai menerima laporan pembawa uang tunai melakukan pemeriksaan atas kebenaran pemberitahuan dibandingkan dengan jumlah yang sebenarnya dibawa dan apabila yang dibawa ke dalam daerah pabean adalah uang tunai rupiah maka pejabat Bea dan Cukai juga melakukan pemeriksaan atas keaslian uang rupiah tersebut. 


\section{Pertanggungjawaban Pelaku Pembawa Uang Tunai Dalam Pemberantasan Pencucian Uang Menurut Undang-Undang Pencucian Uang.}

Aturan Undang-Undang Pencucian Uang mengelompokkan pelaku pembawa uang tunai sebagai subjek hukum di dalam Pasal 35. Undang-Undang Pencucian Uang membebankan kepada pelaku bersangkutan dengan tidak perlu pembuktian kesalahan pada pelakunya yang dapat dilihat dalam Pasal 35 yaitu penuntutan pidana dilakukan terhadap perserorangan atau individu. Jenis sanksi yang dijatuhkan dalam Undang-Undang Pencucian Uang adalah sanksi administrasi yaitu pidana denda $10 \%$ dari Rp 300.000.000,00.

\section{Menurut Peraturan Tata Cara Membawa Uang Rupiah Keluar atau Masuk Wilayah Pabean Republik Indonesia.}

Bank Indonesia sebagai bank sentral yang mempunyai kepentingan untuk menjaga stabilitas nilai rupiah mengatur Pembawa Uang Tunai juga dimaksudkan sebagai subjek hukum dalam kewajiban memberitahukan kepada Direktorat Jeneral Bea Cukai.

Peraturan Bank Indonesia menerapkan pertanggungjawaban pidana pelaku bersangkutan dengan tidak dibuktikan kesalahan terhadap pelaku yang dapat dilihat dalam Pasal 6 yaitu penunututan pidana dilakukan terhadap perserorangan atau individu. Jenis sanksi yang dijatuhkan dalam Undang-Undang Pencucian Uang adalah pidana denda sebesar 10\% dengan batas maksimal Rp 300.000.000,00.

\section{Menurut Peraturan Tata Laksana Pengeluaran dan Pemasukan Uang Tunai}

Peraturan Direktorat Jenderal Bea Cukai terkait Tata Laksana Pengeluaran dan Pemasukan Uang Tunai menerapkan pertanggungjawaban pidana pelaku yang bersangkutan dengan tidak dibuktikan kesalahan terhadap pelaku yang dapat dilihat dalam Pasal 7 yaitu penunututan pidana dilakukan terhadap perserorangan. Jenis sanksi yang dijatuhkan dalam Undang-Undang Pencucian Uang adalah pidana denda 10\% dengan batas maksimal Rp 300.000.000,00. 


\section{Kesimpulan}

1. Dari sisi penegakkan hukum, guna pencegahan pencucian uang, jika tidak ada yang melapor maka PPATK dan Bea Cukai berwenang menolak pembawaan Rp 100.000.000,00 begitu pula Bank Indonesia tidak mengijinkan pembawaan uang tunai tersebut.

2. Pertanggungjawaban bagi pelaku pembawa uang tunai yang melanggar kewajiban pelaporan seharusnya UUPPTPPU memberikan sanksi denda 10\% dengan batas maksimal Rp 300.000.000,00 sebagai kepatuhan terhadap larangan kepada pelanggarnya serta menghindarkan kesimpangsiuran dalam pelaksanaan ketentuan pembawaan uang tunai sehingga sarana tersebut sangat efektif terhadap ketentuan kewajiban pelaporan pembawaan uang tunai.

\section{Daftar Bacaan}

\section{Buku}

Hernold Ferry Makawimbang, Memahami dan Menghindari Perbuatan Merugikan Keuangan Negara Dalam Tindak Pidana Korupsi dan Pencucian Uang (Thafa Media 2015).

Garnasih, Yenti Anti Pencucian Uang Sebagai Strategi Untuk Memberantas Kejahatan Keuangan (Profit Oriented Crimes) (2006) 2 Jurnal Hukum Progresif.

Yati Garnasih, Kriminalisasi Pencucian Uang (Universitas Indonesia Fakultas Hukum Pasca Sarjana 2003).

M. Giovanoli, dari Bank International Settlement dalam makalah Grace Y. Bawole, Sistem Pembuktian dalam Tindak Pidana Pencucian Uang di Indonesia Menurut Undang-Undang Nomor 23 Tahun 2004 (Fakultas Hukum Universitas Sam Ratulangi 2011).

Yudi Kristiana, Pemberantasan Tindak Pidana Pencucian Uang Perspektif Hukum Progresif, cet. 1 (Thafa Media 2015).

Adrian Sutedi, Hukum Perbankan : Suatu Tinjauan Pencucian Uang, Merger dan Kepailitan (Sinar Grafika 2008).

Sutan Remy Sjahdeini, Seluk Beluk Tindak Pidana Pencucian Uang dan Pembiayaan Terorisme (Pustaka Utama Grafiti 2004). 
Wiyono, Pembahasan Undang-Undang Pencegahan dan Pemberantasan Tindak Pidana Pencucian Uang, cet. 2, (Sinar Grafika 2014).

Ivan Yustiavandana, et.al, Tindak Pidana Pencucian Uang di Pasar Modal (Ghalia Indonesia 2010).

\section{Jurnal}

Toetik Rahayuningsih, Analisis Peran PPATK Sebagai Salah Satu Lembaga Dalam Menanggulangi Money Laundering Di Indonesia (2013) 28 Yuridika.

\section{Laman}

Andri Gunawan, Erwin Natosmal Oemar, membatasi transaksi tunai peluang dan tantangan, http://www.ilr.or.id/wp-content/upload/2013/05/membatasiFINAL-03-BW.pdf, dikunjungi pada tanggal 1 Oktober 2014.

Yunus Husein, "Rancangan Undang-Undang Tentang Pembatasan Transaksi Tunai",http://www.bphn.go.id/data/documents/naskah_akademis_ruu_ tentang_pembatasan_transaksi_tunai.pdf, 2013, h. 6, dikunjungi pada tanggal 28 September 2014.

http://www.ppatk.go.id/files/LaporanKinerjaPPATKTahun20140.pdf, dikunjungi pada tanggal 12 Desember 2015.

http://www.ppatk.go.id/files/LaporanTahunan20141.pdf, dikunjungi pada tanggal 12 Oktober 2015.

\section{Perundang-undangan}

Undang-Undang Pencucian Uang, Lembaran Negara Republik Indonesia Tahun 2010 Nomor 122, Tambahan Lembaran Negara Republik Indonesia Nomor 5164.

Peraturan Persyaratan dan Tata Cara Membawa Uang Rupiah Keluar atau Masuk Wilayah Pabean Republik Indonesia, Lembaran Negara Republik Indonesia Tahun 2002 Nomor 104, Tambahan Lembaran Negara Republik Indonesia Nomor 4231.

Peraturan Tata Laksana Pengeluaran dan Pemasukan Uang Tunai.

HOW TO CITE: Retta Ayu Urip Mawarni, 'Penegakkan Hukum Atas Pengawasan Pembawaan Uang Tunai Berdasarkan Peraturan Perundang-Undangan' (2018) Vol. 1 No. 3 Media Iuris. 